Nepalese Vet. J. 35:47- 54

\title{
Participatory Silage Making and Hay and Silage Mixed Feeding Technology for Winter Feeding to Goats in Jumla, Nepal
}

\author{
R. R. Gyawali ${ }^{*}$, S. Yadav ${ }^{2}$ and D. Yadav ${ }^{3}$ \\ ${ }^{1}$ District Livestock Service Office, Jumla \\ ${ }^{2}$ Regional Directorate of Livestock Services, Surkhet \\ ${ }^{3}$ National Sheep and Goat Research Programme, Jumla \\ *Corresponding author: reshamg91@gmail.com
}

\begin{abstract}
This action research was carried out to demonstrate the method of silage making and its feeding, mixed with chopped hay to goats during feed scarcity periods as coping strategy for winter days in Jumla. Nine farmers took part in on-farm silage production and feeding trial. A total of $29 \mathrm{kids}$ and 16 does as treatment group and 12 kids and 19 does of the similar age group and status as control were selected to compare the body weight gain. The normal practice of feeding was 3-4 hours of grazing daily, occasionally combined with tree fodder (Quercus sp.) in communal pastureland and offering hay for snowfall days in pens. In addition to this, treatment groups were supplemented with mixed silage and chopped hay at the rate of $2 \%$ of body weight on dry matter basis, half each from the silage and hay. The mixture was given daily early in the morning for 45 days from $25^{\text {th }}$ of December to $10^{\text {th }}$ of February, when the average minimum temperature dropped from -2.4 to $-5.4^{0} \mathrm{C}$. Goats consumed about 95\% of the offered amount of silage whereas chopped hay was rejected by about $90 \%$. The result showed that kids gained $0.49 \mathrm{~kg}$ with average daily gain of $10.88 \mathrm{~g}$ and does gained $2.44 \mathrm{~kg}$ with an average daily gain of 54.22 $g$ for the treatment group. The difference between the initial and final body weight was positive for treatment group whereas it was negative for the control. Male kids grew faster by $8.6 \%$, female kids by $6.7 \%$ and does by $12.6 \%$ for silage supplemented group compared to control. It indicated that proper fermented maize fodder silage can be obtained from pits prepared before winter and loss in body weight can be prevented by the supplementation of silage during cold days in high mountains when there is scarce of green forages.
\end{abstract}

Keywords: action research, coping strategy, maize fodder, body weight 


\section{INTRODUCTION}

Mountain region of Nepal has about 13\% of the total goat population. Sinhal and Chyangra are the major breeds and mostly reared under migratory system. High mountain region is highly acknowledged for the communal rangeland pasture resources to meet the forage demands of seasonal migratory animals. But the feed supply is adequate only in the months of June-September; rest of the year animals are forced to face feed scarcity (Pandey and Tiwari, 2002). A substantial shortage of winter fodder as being an important constraint within the transhumant system (Farman and Tetlay, 1991; Dost, 1995). The crisis of animal feed during winter season not only causes nutritional stress but also reduces the capacity to resist the cold stress. In this season, farmers either sell their flocks in lower price or bring their flocks to mid hill districts in search of feed where they should pay more money as levy against grazing. So, the silage technology may be taken as one of the best options. Silage, which is anaerobically fermented green fodder, is valued throughout the world as a source of animal feed during lean months (Ragothaman, et a.,l 2010). The practice of making and feeding silage is limited only in government owned farms in Nepal, mostly focused to large ruminants. The reluctance in the adoption among the farmers may be due to the lack of on farm application of the technology. Furthermore, in high mountain region the temperature factor for proper fermentation of silage and goats' preferences for its consumption was also not assessed at community level. So, aiming for green roughage supplement through silage to local goats during winter period by utilizing maize fodder, this action-oriented study was carried out.

\section{MATERIALS AND METHODS}

An Organized farmers' group (OFG), Jolimungrah Pasu Sewa Samuha, in Dhapa VDC-7 in Jumla district was selected for on farm silage making and feeding practices. As per the decision made from the group meeting, 9 members voluntarily carried out the study on their farms. Irrespective of the variety, farmers sowed the maize seed estimating at double of the rate as for grain production between 3rd and 4th week of June. They took care themselves for the fodder in the field. After two to two and half months of sowing, maize crop was harvested, in 3rd week of September, before coming out the cobs. It was wilted on sunlight for about 3 hours and chopped properly with the help of chaff cutter machine at about the size of 2-3 inches long. Silo pits were dug as per the size required to the owner ranged from 1-3 cubic meters. A polythene sheet was laid down on the pits. Chopped fodder maize was filled with continuous trampling by participants to remove the oxygen as soon as possible from the pits. The pits were sealed with the same polythene sheet at first then with the soil and stones tightly. Sixty-two farmers from KalikaKhetu and Kanakasundari Village 
Development Committees were visited the site and participated actively in the process of chopping and ensiling the maize fodder. After 3 months (3rd week of December) silo pits were opened one by one from a corner and evaluated using the sense of smell, taste and color. Hay prepared traditionally from local grasses (non-legume type) was collected from hay store owned by farmers. Hay was chopped with chaff cutter machine and mixed with silage properly before offering to goats. A total of 29 kids (3-12 months) and 16 non pregnant does of local breed Sinhal were selected to feed the calculated amount of silage and chopped hay. Likewise, 12 kids of the similar age group and 19 does were taken as control group i.e. without silage and hay. Body weight was recorded at each fifteen days' interval, using spring weighing balance. The refusal of feeds if any was weighed once at fortnight. The health status was also observed during the trial period. Daily 3-4 hours grazing occasionally combined with tree fodder (Quercus sp.) in communal pastureland near by the village and offering hay for snowfall days in the pens was the normal practice of feeding. In addition to this, treatment group was supplemented with mixed silage and chopped hay at the rate of $2 \%$ of body weight on dry matter basis, half each from the silage and hay. The mixture was given in common feeder to the goats of individual farmers daily early in the morning from December 25 to February 10 (45 days). The period of one week was considered as an adaptation period. Weather data were collected from climatic field office, Jumla. The quantitative data were analyzed using simple statistical tools and qualitative data as description.

\section{RESULTS}

\section{The weather situation}

The average maximum and minimum temperatures in Jumla from January 2013 to February 2014 were collected and found that the months from November to February were the coldest months of the year when the average minimum temperature fell to $5.4^{\circ} \mathrm{C}$ in December (Figure-1). During the feeding trial period snowfall was recorded three times in the months of January and February. The rainfall was not recorded for the trial period. In the month of October when fodder was ensiled average maximum and minimum temperature was $25.8^{\circ} \mathrm{C}$ and $8.0^{\circ} \mathrm{C}$ which gradually decreased to $16.8^{\circ}$ $\mathrm{C}$ and $-5.4^{\circ} \mathrm{C}$ respectively by December when it was opened.

\section{Quality of silage}

Silage with pleasant aroma, nearly odorless, light sour taste and slightly golden with light green color was found within the pits. There was no mould growth appeared in all pits at opening. 


\section{Preferences of feeds}

The mixture of chopped hay and silage was the new feed to goats. For the first day of offering the mixed, goats of two farmers did not like to eat it. When farmers added a little amount of common salt on the mixed, goats used to consume almost all the amount of silage offered. After few days, no salt was needed to accustom the feed. It was found that almost $95 \%$ of the offered amount of silage was consumed by goats whereas only $10 \%$ of chopped hay was consumed. The intake of chopped hay was nominal and the practically about $1 \%$ of the body weight of animals was consumed only from the silage on dry matter (DM) basis (assuming 35\% DM content).

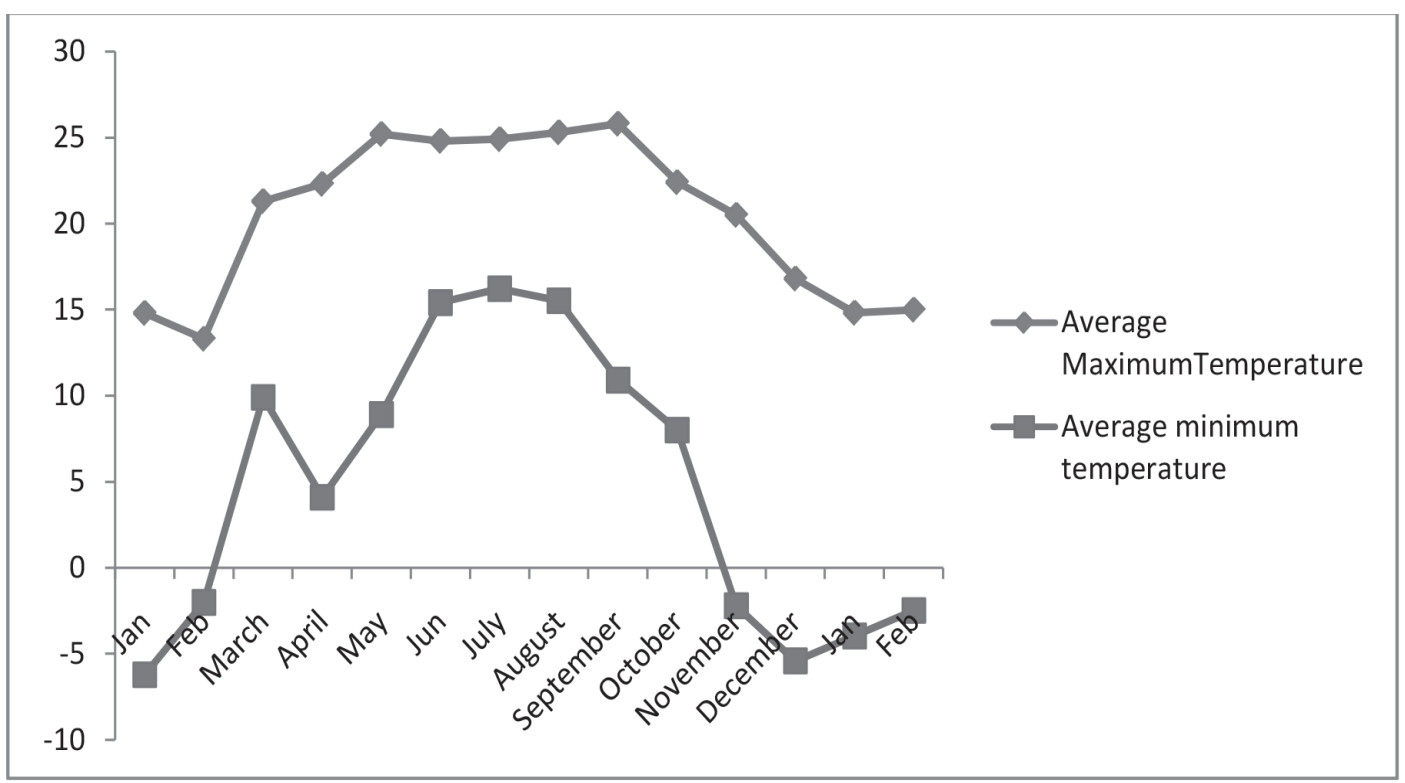

Fig. 1: Average maximum and minimum temperature $\left({ }^{\circ} \mathrm{C}\right)$ in Jumla during January 2013 to February 2014 (Source: Climatic field office, Jumla)

\section{Body weight gain in goats}

The initial and final average body weight is presented in Table 1. It reveals that the average initial body weight of the kids was lower in treatment group than in the control group, whereas the average body weight of doe was lower in control group than that of treatment. The same trend was observed for the final body weight.

The total weight gain in kids was $0.49 \mathrm{~kg} / \mathrm{kid}$, with average daily gain of 10.88 grams and in does it was $2.44 \mathrm{~kg}$ with an average daily gain of $54.22 \mathrm{gm}$ for the treatment group during the trial period, whereas kids and does lost their body weight by 0.03 and $0.84 \mathrm{~kg} /$ animal respectively for the group without silage supplement. 
Table 1: Initial and final body weight of goats $(\mathrm{Kg})$ supplemented silage and hay mixed feed as treatment and without the mixture as control in Jumla, 2014

\begin{tabular}{|l|r|r|r|r|}
\hline & \multicolumn{2}{|c|}{ Control } & \multicolumn{2}{c|}{ Treatment } \\
Animals & \multicolumn{1}{|c|}{ Initial BW } & \multicolumn{1}{|l|}{ Final BW } & Initial BW & \multicolumn{1}{|l}{ Final BW } \\
\hline Kids & $11.83(12)$ & 11.75 & $9.44(29)$ & 9.93 \\
\hline Does & $25.31(19)$ & 24.47 & $26.15(16)$ & 28.59 \\
\hline
\end{tabular}

Note: Figures in parenthesis indicate the number of animals

While considering the sex of kids, the difference (weight gain or loss) between the initial and final body weight was positive for both the males and females in treatment group whereas it was positive only for male kids in control group (Fig. 2). Male kids grew faster by $8.6 \%$ and female kids by $6.7 \%$ and does by $12.6 \%$ for silage supplemented group than the animals without the supplementation (Table 2).

\section{Goat health status}

Health condition of the goats was also observed during the period of feeding trial. No clinical signs of contagious diseases were noticed during the 45 days of feeding trial. Two kids with lower body scores were infested with external parasites (lice).

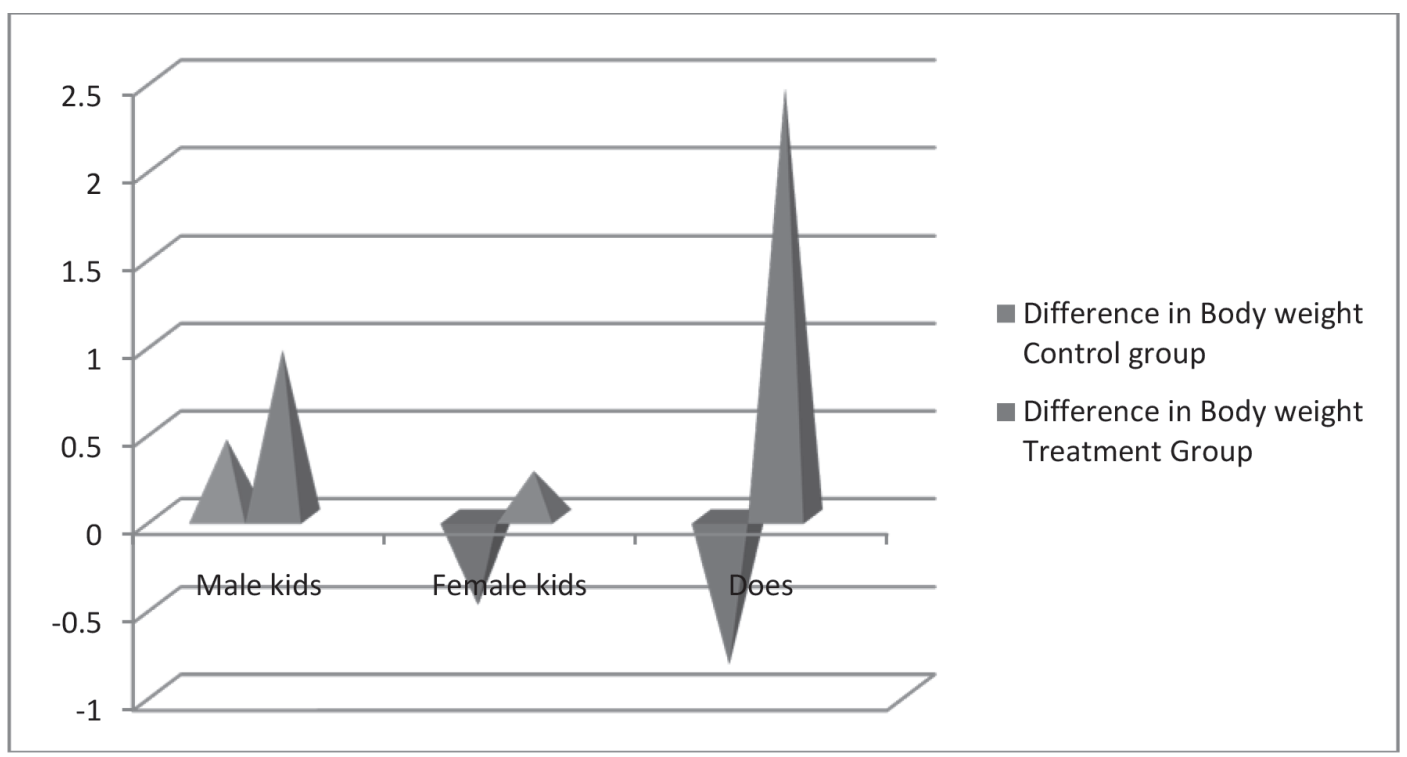

Fig. 2: Positive and negative body weight gain in goats supplemented silage and hay mixed feed as treatment and without the mixture as control in Jumla, 2014. 
Table 2: Body weight gain of goats and differences (\%) between supplemented silage and hay mixed feed as treatment and without the mixture as control in Jumla, 2014

\begin{tabular}{|l|c|c|c|}
\hline \multicolumn{4}{|c|}{ Body weight gain in percentage } \\
\hline \multicolumn{1}{|c|}{ Animals } & Control group (C) & $\begin{array}{c}\text { Treatment Group } \\
\text { (T) }\end{array}$ & $\begin{array}{c}\text { Difference } \\
\text { between C\&T }\end{array}$ \\
\hline Male kids & 4.67 & 13.27 & 8.59 \\
\hline Female kids & -4.10 & 2.61 & 6.70 \\
\hline Does & -3.32 & 9.33 & 12.65 \\
\hline
\end{tabular}

\section{DISCUSSION}

The temperature record over the period of one year in Jumla shows that the environmental temperature fell down abruptly from 8 to $-2{ }^{\circ} \mathrm{C}$ from October to November, December to February were the coldest months. The quality of silage in silo pit was found good may be due to well fermentation and formation of lactic acid due to the proper ambient temperature and anaerobic condition within the sealed pit . Regarding the aroma/odor, it was mentioned that nearly odorless is the characteristic of well fermented silage (Charley B and Schmidt, 2014). More preferences in consuming the silage may be due to its green nature as compared to the chopped dry hay. The normal practice among the farmers was offering hay without chopping. The findings matches, while compared to dry roughages (wheat and rice straw) between whole and chopped forms but in contrast to the findings goats' preferred chopped hay of clover and other high quality forages over the un chopped material (Abdel and Alla ,1999). The findings of Abi et al., (2008) matches the present finding, which revealed that in transhumant system male kids, female kids and does gained lower body weight in winter period than the summer period and they also found that male kids gained more live weight than female in winter period. In the same study, does lose the body weight during the period.

In this experiment too low gain in body weight of the goats may be due to the low availability of forage in pastureland combined with cold stress and the result obtained positive weights was practically the supplement of silage only. The lowest average daily weight gain/goat was observed on transhumance system was also supported by Khanal (2012) and Osman et al., (2009). Malisetty et al., (2013), revealed that Nellore ram lambs gained average daily body weight of $32.33 \mathrm{~g}$ with sole silagebased feed ration. The lost in body weight during winter season in migratory ewes was also found in a study of Dhaubadel (2000). 


\section{CONCLUSION}

Goats in high mountains areas are either confined around the farmers' settlement or brought down to the mid hills pasture during colder days of the year. While around the villages, it is crucial to meet the feed demand of animals. The practice of making silage from the maize fodder from pit silo was successful at the community level. Similarly, body weight loss due to deficit of feed combined with cold stress in goats could be prevented by the supplement of a little amount of maize silage (approximately $1 \%$ of body weight on DM basis) during winter season.

\section{ACKNOWLEDGEMENT}

The authors are thankful to Mr. Rajendra Prasad Bhari and his team at High Value Agriculture Project (HVAP) Surkhet for the financial support to carry out the study; Mr. Lumanidhi Pandey, Senior scientist of National Sheep and Goat Research Program, Guthichaur, Jumla, NARC, for his technical guidance and cooperation; and the executives and the members of Jolimungrah Pasu Sewa Samuha, Dhapa for their active participation to accomplish the work.

\section{REFERENCES}

Abdel-Moneim A.Y , M.S Abd-Alla (1999).Department of Animal Production, Faculty of Agriculture, Cairo University, Giza, Egypt DOI: http://dx.doi. org/10.1016/S0168-1591(99)00045-3

Abi Saab, S. E. Hajj1, B. Abi Salloum and E. Rahme (2008). Seasonal and altitudinal variations on adaptation, growth and testicular activity of Baladi goats with vertical transhumance in eastern Mediterranean. Lebanese Science Journal, Vol. 9: No. 1, 2008.

Charley B and Renato J. Schmidt (2014). Use your senses to evaluate silage.Retrieved from https://www.progressiveforage.com/forage-types/silage

Dhaubhadel TS (2000). Stress caused by a shortage of winter feed as a constraint upon the migratory system of sheep management in the western hills of Nepal. Proceeding of the 3rd National Animal Science Convention (NASA), Lalitpur, Khumaltar, Nepal.Aug 27-28, 2000, pp 97-102.

Dost, M. (1995). Fodder production in Northern Areas. Report number Pak/86/027. National Agriculture Research Council, Park road, Islamabad, Pakistan. pp. $1-53$.

Farman, A. and K. A. Tetlay, 1991. Dynamics of livestock development in Northern Areas of Pakistan: AKRSP, Gilgit. pp. 20 - 21. 
Khanal B. (2013). Effect of feeding system on growth Performance of high hill goat The Proceedings of National Workshop on Research and Development Strategies for Goat Enterprises in Nepal. (Eds. Gurung T.B., Joshi B.R., Singh U.M., Paudel K.P., Shrestha B.S., Rijal K.P. and Khanal D.R.), NARC, Kathmandu, April 2013.PP 233-239.

Malisetty V, Yerradoddi RR, Devanaboina N, Mallam M, Cherala HK, Admal RR and Manthani GP (2013). Effect of feeding maize silage supplemented with concentrate and legume hay on growth in Nellore ram lambs, Vet World 6(4):209-213, doi:10.5455/vetworld.2013.209-213.

Osman, J.S., Waldron, D.F., Griffin, D.B. and Savell.J.W. (1999). Effect of breedtype and feeding regimen on goat carcass traits. J. Anim. Sci, 77:3215-3218.

Panday, S.B. and Tiwari, M.R. (2002). Fodder resources and pastoral systems in Nepal. In: Proceedings of the 5th meeting of the Temperate Asia Pasture and Fodder Network (TAPAFON), RNR Research Centre Bajo, Wangdue, Bhutan, 30th Apr- 4th May, Pp 71-78.

Ragothaman, Venkataramanan. Chirukandoth, Sreekumar. Rishipal, Anil kumar. Selvaraj, P., Nainar, M. Vidhya. and Iyue, Mathagowder. (2010) Effect of jaggery on the quality and intake levels of maize silage. Trop. Ani. Health and Prod. 42(5):1027-1029.

Yokota H., T.Okajima and M.Olishima (1991). Effect of environmental temperature and addition of molasses on the quality of Napier grass (Pennisetum Purpureum Schum.) silage. AJAS 1991 vol, 4(No.4): 377-382. 